\title{
A epistemologia transdisciplinar nos pressupostos da teoria da complexidade e no contexto da organização do trabalho
}

\section{The transdisciplinary epistemology in the theory of complexity of complexity and in the contexto of work organization}

\author{
Osmar Ponchirolli* \\ Juarez Francisco da Silva**
}

\begin{abstract}
Resumo: A teoria da complexidade parte basicamente da ideia de que todo sistema constitui uma unidade complexa, comportando diversidade e multiplicidade, inclusive antagonismos. O ecossistema e a biosfera dão sentido pleno ao termo complexo, que significa entrelaçamento, portanto aquilo que está entrelaçado em conjunto constitui um tecido estreitamente unido, embora os fios que o constituam sejam extremamente diversos. A partir da obra O Método, de Edgar Morin, este estudo se concentra primeiramente na elaboração das características do conceito de transdisciplinaridade; em seguida nos pressupostos da teoria da complexidade, para somente a seguir verificar como a teoria da complexidade pode dialogar com as organizações do trabalho e com a área da educação, que também se caracteriza como uma empresa, pois a formação profissional se fundamenta teoricamente no ambiente educacional. O pensamento complexo pretende ultrapassar as entidades fechadas ou as disciplinas, como um meio necessário para conceber o fundamental. Seja diretamente na área da educação, na construção do pensamento complexo ou nas organizações como campo do conhecimento, a complexidade se mostra disponível para dialogar com todas as demais teorias do conhecimento, considerando o método transdisciplinar como norteador dessa abordagem. O fio condutor da observação dos pressupostos da epistemologia proposta pela complexidade considera que aquele que pesquisa é antes um pesquisador de si mesmo, por isso a vida de Edgar Morin, idealizador da teoria da complexidade, é o principal elemento constituinte das considerações finais deste estudo.
\end{abstract}

Palavras-chave: Transdisciplinaridade. Complexidade. Educação. Organização. Método.

"Filósofo, teólogo, Licenciado em História e Sociologia. Especialista em Didática do ensino Superior. Mestre e Doutor pela Universidade Federal de Santa Catarina. Professor da FAE - Centro Universitário e da Faculdade Padre João Bagozzi em Curitiba. E-mail: ponchirolli1965@gmail.com 


\begin{abstract}
The theory of complexity basically comes from the idea that every system is a complex unit holding diversity and multiplicity, even antagonisms. The ecosystem and biosphere give full meaning to the term complex, which means interlacing, therefore, what is interlaced together, it consists of a closely woven together fabric, although the wires that constitute are extremely diverse. From the work of Edgar Morin's "The Method", this study focuses primarily on the development of the defining features of transdisciplinarity, then the assumptions of complexity theory to organizations can engage with the work then only check how complexity theory and the area of education, which characterizes itself as a company, because the training is grounded theoretically in the educational environment. Complex thinking aims to overcome the closed entities or the disciplines, as a necessary means to conceive the fundamental. Either directly in the area of education, in the construction of complex thinking or in organizations as a field of knowledge, the complexity is available to communicate with all other theories of knowledge, considering the transdisciplinary method as a guide for this approach. The thread of the observation of the assumptions of epistemology proposed by the complexity considers that the one who researches is, before of anything, a researcher of himself, so the life of Edgar Morin, founder of the theory of complexity, is the main constituent of the final considerations of this study.
\end{abstract}

Keywords: Transdisciplinarity. Complexity. Education. Organization. Method.

Recebido em: 11/11/2011. Aceito em: 20/11/2012.

\section{Introdução}

A complexidade, de acordo com a etimologia, é como uma disciplina que se abre para dialogar com outros campos, além das limitações ou dimensões de saberes específicos, de especialidades para espacialidades comuns ao universo da pesquisa transdisciplinar.

O pensamento complexo se define como a busca de um modo de pensar em que o mistério e o caráter multidimensional do real sejam considerados ou respeitados, pois o objeto do conhecimento é determinado pela cultura, condição social, história e até por determinações cerebrais. Por isso, Morin (2005) apresenta na obra O Método o desenvolvimento de uma busca de método.

Essa busca parte da articulação da vida própria de Morin, com as propostas teóricas que denominou de primeiro período das reorganizações genéticas, observando que as ideias avançam nas supostas contradições dialéticas. Por escolha pessoal de argumentos, elege a palavra dialógica para representar sua concepção de mundo e a caracteriza como o segundo reorganizador genético. A partir de 1960, em contato com a cibernética, redefine o terceiro ciclo do chamado período das reorganizações genéticas, e prepara as bases epistemológicas para lançar o pensamento complexo.

Portanto, é na cibernética, na teoria dos sistemas e da informação, que Morin (2010) fundamenta as bases para o pensamento complexo, consistindo em elaborar bases fundamentadas nessas teorias.

As bases ou princípios do pensamento complexo são também denominados de "operadores da complexidade", e se constituem do princípio dialógico que significa entrelaçar as coisas que estão separadas aparentemente; do princípio recursivo que significa que toda causa produz um efeito e esse gera a causa, semelhante a um anel ou circuito recursivo; e o operador ou princípio hologramático que indica que não é possível dissociar o todo das partes, gerando assim a ideia de totalidade e que nunca será igual à soma das partes.

A base epistemológica ou a forma de conhecer as coisas para a teoria da complexidade é denominada por Morin (2005) de transdisciplinar, pois além de ser disciplinas que formam elos ou que colaboram entre elas, são uma forma de 
pensar que transcende as fronteiras da disciplina, a fim de construir um meta ponto de vista acerca da vida, da terra, do cosmos, das artes, dos homens.

A palavra epistemologia é definida por Freire (2001) como a teoria do conhecimento, uma parte da filosofia cujo objeto é o estudo reflexivo e crítico da origem, natureza, limites e validade do conhecimento humano. Essa forma de conhecer as coisas leva a buscar a natureza, as etapas e os limites do conhecimento humano, os processos cognitivos individuais e sociais, dando possibilidades de reflexão.

A epistemologia transdisciplinar diz respeito ao que está ao mesmo tempo entre as disciplinas, através das diferentes disciplinas e além de toda disciplina, segundo Morin (2010). Sua finalidade é a compreensão do mundo atual, e um dos imperativos para isso é a unidade do conhecimento, que se fundamenta metodologicamente em três pilares: os níveis de realidade, a lógica do terceiro incluído e a complexidade.

A proposta teórica transdisciplinar trata de mais uma forma de refletir e conhecer os fenômenos da vida, tão importante quanto as outras epistemologias vigentes, mas que se dedica ao diálogo intermitente com todo tipo de pesquisa.

A pesquisa chamada disciplinar, segundo Nicolescu (1999), se refere a um único nível de realidade. Na maioria dos casos, ela só diz respeito a fragmentos de um só nível de realidade. Como a transdisciplinaridade interessa pela dinâmica gerada pela ação de diversos níveis de realidade ao mesmo tempo, esta dinâmica passa necessariamente pelo conhecimento disciplinar que, por sua vez, é clareado de uma maneira nova e fecunda pelo conhecimento transdisciplinar. Nesse sentido, as pesquisas disciplinares e transdisciplinares não são antagônicas e sim complementares.

Para Nicolescu (1999), a pluridisciplinaridade é uma forma de pesquisa que se dedica ao estudo de um objeto de uma única disciplina por diversas disciplinas ao mesmo tempo. Por exemplo, a filosofia marxista pode ser estudada pelo enfoque da filosofia entrecruzada com a física, a economia, a psicanálise ou a literatura. O objeto em questão sairá, assim, enriquecido pelo cruzamento de várias disciplinas e o conhecimento do objeto em sua própria disciplina é aprofundado por um importante aporte pluridisciplinar, mas a serviço apenas dessa disciplina.

Outra forma de pesquisa, a interdisciplinaridade diz respeito à transferência dos métodos de uma disciplina a outra. Conforme Nicolescu (1999) é possível distinguir três graus de interdisciplinaridade: 1) um grau de aplicação; 2) um grau epistemológico; e 3) um grau de geração de novas disciplinas.

Embora seja possível caracterizar a distinção da transdisciplinaridade com relação à disciplinaridade, à pluridisciplinaridade e à interdisciplinaridade, conforme Nicolescu (1999) seria muito perigoso considerar essa diferença como absoluta, pois com isso a transdisciplinaridade seria esvaziada de todo o seu conteúdo e a eficácia de sua ação seria reduzida a nada. Parece conclusivo que a disciplinaridade, a pluridisciplinaridade, a interdisciplinaridade e a transdisciplinariade são as quatro flechas de um único arco: o do conhecimento.

Outra base fundamental que sustenta a teoria da complexidade é o que Morin (2005) chamou de tetralogia, ou seja, o que concebe como as ideias de ordem, desordem, interação e reorganização. Qualquer atividade de todo ser vivo é formada por essa tetralogia paradigmática, seja na vida pessoal, profissional, educacional, e em todas as relações.

O que realmente caracteriza a teoria da complexidade como um pensamento transdisciplinar? Como esse método se constitui como ciência? De que forma o pensamento complexo se articula com a ideia de organização do trabaIho no mundo atual? Como a psicologia de base psicanalítica identifica características relevantes na história da vida pessoal do autor, que possam ter vinculação direta com a pesquisa sobre a complexidade? A transdisciplinaridade pode facilitar as interações de caráter heterogêneo no campo das subjetividades e da produção de conhecimento?

Essas são questões que a pesquisa teórico-empírica, de natureza exploratória e bibliográfica tenta desvendar neste texto, ou ao menos compreender como o autor teceu o conceito de complexidade, como pode dialogar com as organizações do trabalho e com a área da educação, que também se caracteriza como uma empresa, pois a formação profissional se fundamenta teoricamente no ambiente educacional. 
A vida de Morin desde cedo é conduzida a partir de experiências em áreas diversas, em lugares diferentes, por tradições múltiplas e pesquisas variadas. Parece que, para elaborar conceitos complexos, é preciso também interagir com as experiências que norteiam o conjunto de saberes, indicando que o comportamento humano é o que fundamenta a possibilidade de elaborar conceitos científicos a partir de si mesmo, como sugere a teoria psicológica de base analítica, utilizada como referência para subjetivamente identificar características do comportamento do autor na constituição da proposta teórica.

Esta pesquisa também se dedica a observar a vida do autor, relatada na própria obra, considerando que sua teoria inicia na relação de pressupostos históricos da sua própria vida e, por isso, constitui fundamento psicológico para tecer conceitos em ciência, considerando fundamentalmente a inspiração do observador como principal objeto da própria pesquisa.

\section{Biografia de Edgar Morin}

Edgar Morin nasceu em 08 de julho de 1921, em Paris e viveu nessa cidade com sua família. Seus avós maternos eram de origem italiana e os ascendentes paternos, como muitos sefarditas ${ }^{1}$, haviam sido expulsos da Espanha em 1942. Contudo, as famílias celebravam juntas as festas tradicionais, pois consideravam como motivo social e não atribuíam especial atenção ao fator religioso, de menor importância.

Circuncisado na tradição religiosa, Vidal Nahoum, o pai de Morin, também o fez cumprir a obrigação da religião, mesmo não seguindo rigorosamente os preceitos dessa tradição.

A morte de sua mãe, Luna, aos trinta anos provocou "uma Hiroshima interior" nele. O nome Luna, segundo Morin (2010), também significa lua e corresponde a uma deusa, à qual diversas civilizações rendem culto costumeiramente, assim como ele o faz a cada lua cheia em que

\footnotetext{
${ }^{1} \mathrm{O}$ sefardi é o judeu cuja ascendência remonta às comunidades judaicas ibéricas (Espanha e Portugal), estabelecidas na Ideade Média e dispersas por várias regiões após a expulsão da Espanha em 1942 (HOUAISS, 2000). A palavra hebraica sefardi significa espanhol (MORIN, 2010, p. 28).
}

murmura o canto sagrado da "Casta Diva"2 em sua homenagem.

No dia da morte de sua mãe, Morin estava com nove anos e naquele dia na saída da escola seu tio Jo o esperava, mesmo sendo fato incomum a presença deste, ele não estranhou, nem percebeu do que se tratava. A explicação do tio foi de que os seus pais viajaram para tratamento de saúde.

Dois ou três dias depois da morte da mãe, foi levado ao jardim Martin-Nadaud, próximo ao cemitério Père-Lachaise e lá seu pai o esperava. Somente naquele instante é que percebeu que sua mãe estava morta, mas assim mesmo disfarçou que a tudo compreendia.

O fato de seu pai não tocar objetivamente no assunto nem conversar sobre a morte da esposa, gerou em Morin grande irritação, pois para ele o pai subestimou sua capacidade de assimilar conscientemente a morte da mãe.

A tia materna chamada Corinne disse que Luna tinha viajado para o céu e que talvez um dia voltasse, mas isso provocou ainda mais ódio em Morin, pois para ele era tudo mentira contada para uma criança.

Morin (2010) conta que esse episódio em sua vida o fez conservar grande aversão pela mentira, pois relata que odiou o pai por ter-lhe impedido de despedir-se de sua mãe, odiou sua tia por pedir que agora a considerasse sua mãe. Para ele, o pai querendo evitar uma emoção no filho, causou um choque do qual nunca se recuperou.

Para que o pai e a tia acreditassem que ele não sentia falta da mãe, evitou a vida toda em falar sobre o fato e somente trinta anos mais tarde, no seu livro Autocrítica é que Morin (2010, p. 9) comentou sua dor.

Sua tia Corinne já ajudava a cuidar dele, mesmo antes de sua mãe falecer, porém Morin (2010, p. 9) nunca acompanhou sua tia ao cemitério para homenagens do aniversário de morte, indo ao túmulo somente quando adulto, na ocasião do enterro de um dos parentes. Para ele, "minha mãe era somente minha, minha dor era somente minha, eu não queria partilhar nem uma nem outra com eles".

\footnotetext{
2 "Casta Diva" é o canto sagrado chamado assim em uma área da ópera Norma dedicado à lua (MORIN, 2010, p. 8).
} 
Durante sua infância e adolescência, Morin (2010) comenta que sua mãe esteve presente nos seus sonhos, mas desaparecia quando ele acordava e isso era desesperador. Trancava-se dentro de armários para chorar, tentando conter os soluços para que o pai não ouvisse, e esperava os olhos secarem para sair, mantendo o rosto sereno e aparentemente tranquilo ou indiferente para o pai.

Um dia ouviu sua tia Corinne comentar com seus filhos de que havia na família uma tia chamada Lucinda que morreu por causa de muita tristeza, e nesse momento lembrou que certo dia chamou sua mãe de "malvada". Teria sido esse o motivo da morte da sua mãe? Se a tristeza foi a causa da sua morte, teria sido ele o causador da morte dela?

Segundo Morin (2010, p. 11), a culpa pela morte da sua mãe, mesmo na idade atual, está sempre pronta para reaparecer e lembra que somente conseguiu falar dela pela primeira vez aos dezenove anos de idade, quando ficou refugiado no início da Segunda Guerra Mundial, em Toulouse. Falou e chorou para um colega que vendia jornal nas ruas de Paris.

No fim de 1980, em quadro de depressão psicológica, Morin (2010) levou um amigo e psicólogo para visitar o túmulo da mãe e essa era a segunda vez que visitava o cemitério.

Em entrevista concedida para Tager (apud MORIN, 2010), até 2008 Morin não sabia com exatidão a localização do túmulo, mas inconscientemente conhecia onde sua mãe está enterrada.

Quase aos cinquenta anos de idade e morando na Califórnia (EUA), Morin (2010) convidou o pai e Corinne, que nesse momento estavam casados, para visitá-lo depois de trinta anos que não viviam mais juntos. Na noite anterior à chegada deles, Morin teve um sonho com sua mãe que descreve da seguinte maneira:

Estou sobre o flanco de uma colina, embaixo há uma estação de trem e acima uma estrada. Um carro estaciona, os passageiros descem e se dirigem à estação. Entre eles vejo minha mãe. Corro até ela e o trem chega. Ela me beija, eu the digo adeus e ela se vai (MORIN, 2010, p. 13).

Para Morin (2010) esse sonho foi o momento em que se despediu da sua mãe, e a relação com seu pai e Corinne se apaziguou muito.

Novamente Morin (2010, p. 13) disse adeus à sua mãe, quando também se despediu por três vezes de sua esposa Edwige no leito de morte, no momento de fechar o caixão e no cemitério. Esta além de esposa era vista por Morin como uma "mãezinha".

Ao falar do seu nascimento, Morin (2010) utiliza a expressão de natimorto, considerando que sua mãe tinha uma lesão no coração e por isso foi aconselhada a não ter filhos. Na primeira gravidez, foi ajudada eficazmente pelos remédios de uma aborteira, mas na segunda não foi possível abortar. "Ainda um feto, recusei-me a sair e me agarrei ao ventre de minha mãe", comenta Morin (p. 13).

Esse trágico nascimento de Morin, em que a vida da sua mãe dependia da morte do filho, inclusive com o estrangulamento do cordão umbilical que quase o matou, foi-lhe contado por carta pelo pai, na ocasião da celebração de seus 54 anos.

Na noite em que recebeu a carta, a insônia o fez revisitar o momento que o médico segurou-o pelos pés, com palmadas na face, no peito e por toda parte até emitir o primeiro grito e salvar a mãe e o bebê. Desse nascimento compreendeu que pode haver alguma ligação com sensações de sufocamento ao longo da vida, como uma grande necessidade de ar que se transforma em bocejo.

Morin (2010) lembra ainda que logo após a morte de sua mãe, no primeiro verão, contraiu o diagnóstico raro de febre aftosa, como nos bovinos, e chegou a ter febre de 41 graus.

Como era filho único, ele teve uma relação muito próxima com sua mãe e lembra que ela o mimou com roupinhas de marinheiro e todo tipo de agrado.

Morin (2010) cita que alguns historiadores e a arte em geral, como a música de Beethoven, contribuíram para ele conseguir enfrentar a vida. Inclusive sua ligação com o partido comunista e os quinze anos fazendo política foram formas de consumar o desespero por uma redenção imaginária.

Das várias experiências durante a guerra, fugas criativas e da possibilidade de ter sobrevivido após ser perseguido, talvez a mais importante tenha sido o momento em que dentre os 
pseudônimos que usou durante esse período, se apresentou numa reunião dos companheiros resistentes em Toulouse com a identidade de Manin, entendido como Morin pela sonoridade da língua francesa. A partir de então, "sou Nahoum e sou Morin. Mas não sou uma pessoa dividida. Minha dupla identidade é para mim como meus dois olhos: eles me fazem enxergar melhor" (MORIN, 2010, p. 122).

A curiosidade literária desse autor parece que desde cedo era aguçada e desenfreada, pois antes mesmo dos vinte anos já havia lido obras como o Bhagavad-Gita, os Evangelhos, as biografias de Vivekananda e de Ramakrishna. Buscava seu caminho nas tradições espiritualistas orientais e o caminho de Buda parecia superior a tudo o que conhecia no Ocidente, mas foi capital a iluminação adquirida com a leitura da obra sobre a Fenomenologia do Espírito de Hegel.

Por isso, Morin (2010, p. 88) se considera um pensador marxista-hegeliano, com contribuições de Freud, Jung, Ferenczi, Otto Rank e de filósofos como Jankélévitch e Bachelard e sente-se mais integrado com as leituras de Heráclito, Pascal, Kant, Nietzsche, Husserl e Heidegger. $\mathrm{Na}$ sua forma de integração cultural, se reconhece como um judeu-gentio ${ }^{3}$ e pós-marrano ${ }^{4}$.

Depois de várias experiências militares durante e pós a guerra, com muitas viagens e pessoas diferentes, ligação com partidos políticos e ideologias, é inevitável a separação da esposa Violette. Deixou para ela todos os bens materiais, inclusive a conta bancária, saindo de casa com alguns livros e a experiência de jamais ser escravo das coisas como objetos e bens materiais.

Uma grande experiência para sua vida como pesquisador foi a que viveu na comuna de Plozévet, na região da Bretanha. O dinheiro investido em pesquisas não gerou para a sociedade o que se esperava sendo os professores da comunidade acusados de desvio dos recursos financeiros. Morin (2010) afirma ter cumprido rigorosamente com sua pesquisa, e do dinheiro

\footnotetext{
${ }^{3}$ Judeu-gentio para Morin (2010, p. 88) significa o judeu moderno que, formado na e pela cultura humanista europeia, torna-se cidadão de uma nação.

${ }^{4}$ Os marranos eram os judeus da Espanha e Portugal que foram forçados a se converter ao cristianismo no fim do século XV (MORIN, 2010, p. 89).
}

ele somente sabe da pequena parte que the coube e que foi retribuído com trabalho, mas esse fato deixou sua vida marcada pela calúnia de ter utilizado dinheiro público de forma não muito correta.

Aos quarenta anos, em 1961, foi transportado para o Hospital Monte Sinai em Nova York onde ficou em coma por um tempo, mas renasce decidido a viver suas verdades e reformar a vida.

Casou-se 1978, perto dos sessenta anos, com Edwiges, o grande amor da sua vida, e a partir dessa relação emocional estabeleceu para si quatorze mandamentos que sustentam suas atitudes, como sujeito da própria história complexa (MORIN, 2010, p. 377) que são:

- O contrário de uma verdade profunda é outra verdade profunda (retirado de Pascal e de Niels Bohr);

- O melhor dos mundos é também o pior (Deus e Satã são o mesmo);

- Tudo que não se regenera degenera (o que quer dizer, também, que a certeza jamais é alcançada);

- Rir, amar, chorar, compreender;

- Esperar pelo inesperado;

- Lutar em duas frentes;

- Resistir à crueldade do mundo e à barbárie humana;

- Não sacrificar o essencial à urgência, mas obedecer à urgência do essencial;

- Devotar-se ao que propicia paixão e compaixão;

- Manter sempre alerta a razão na paixão e sempre presente a paixão na razão;

- Preservar a revolta na aceitação e a aceitação na revolta (de Beethoven);

- Amar o frágil e o passageiro (Amar tudo aquilo que não se verá duas vezes, de Alfred de Vigny);

- Pensar em aumentar a vida de seus dias muito mais do que os dias de sua vida (de Rita Levi-Montalcini);

- Renascer e renascer até a morte.

Em 1984, a morte do pai aos 90 anos de idade, em Mônaco, foi mais um golpe para Morin (2010), pois já havia compreendido seu respeito 
e amor pela forma como o pai se dedicou exaustivamente na criação do filho, mesmo quando fazia chantagens de que iria morrer caso Morin não cumprisse com os seus pedidos. Construíram uma forte relação afetiva nos últimos de vida do pai e, seis anos após a morte deste, o corpo de Vidal é transferido para junto de onde a mãe fora enterrada, no cemitério Père-Lachaise.

Alguns meses após a morte do pai, Morin teve um sonho em que estava diante do túmulo deste e escutou Vidal Ihe dizer: "Edgar, meu querido, agora você pode ir. Não esqueça sua pasta. O luto acabou." A partir desse sonho, Morin (2010, p. 231) se dedica ao livro Conhecimento do Conhecimento ${ }^{5}$, publicado em 1986.

Em 1986, Morin (2010) comenta que teve indícios de uma depressão psicológica e teve dúvidas se deveria seguir com $O$ método ou se deveria interromper por um período. Seu psicoterapeuta sugeriu que seguisse o que estava sentindo no momento, ou seja, interromper tal obra e escrever um livro em homenagem ao seu pai. Assim o fez e em 1989 publicou o livro Vidal e os seus, escrito num computador na comunidade italiana, Parma, entre lágrimas e sorrisos, para depois voltar e seguir com a obra interrompida.

Claude Allègre, ministro da educação do primeiro ministro francês Lionel Jospin, convidou Morin para presidir um conselho para a reforma do ensino secundário em 1998.

Diante de um grupo de quarenta membros competentes e oriundos de diversas disciplinas, Morin (2010) preparou inicialmente oito jornadas temáticas, segmentando em cada jornada os temas sobre o universo, a terra, a vida, a humanidade, a história, as línguas, civilizações e artes, as culturas adolescentes, mas o tema na oitava jornada foi sobre religar os saberes.

As proposições pedagógicas estão publicadas em A cabeça bem feita e no mesmo contexto da educação, a Unesco pediu um texto de valor universal para ser introduzido nos programas das escolas de ensino primário e secundário. Esse texto foi publicado em livro com o título Os sete saberes necessários à educação do futuro, mas na França não foi muito vendido como em outros lugares do mundo.

\footnotetext{
${ }^{5}$ O livro Conhecimento do conhecimento é um dos livros que compõe a obra O método (MORIN, 2008b, p. 232)
}

O desespero por verdades, segundo Morin (2010), fica expresso no engajamento ao comunismo e na resistência no decorrer da Segunda Guerra Mundial. Dessa forma, o ceticismo e a fé não cessam de se combater em sua vida, pois não teve educação religiosa institucional em casa e sua vida impulsionou a busca de verdades após a morte de sua mãe. Também não teve orientação cultural pelo pai, e suas dificuldades foram o principal alicerce para despertar em Morin verdades pessoais que, sem essas experiências, teriam sido impossíveis de serem atingidas.

\section{A pesquisa e o método transdisciplinar}

O termo transdisciplinar historicamente data de 1970, quando Jean Piaget afirmou, durante um congresso sobre interdisciplinaridade, que aquela etapa deveria ser sucedida por uma etapa transdisciplinar, segundo Theophilo ${ }^{6}$. O prefixo trans remete ao que está entre, através e além das disciplinas.

A epistemologia transdisciplinar propõe transcender o universo da disciplina e trazer à tona a multiplicidade dos modos de conhecimento, da potencialização de tendências heterogêneas, seja no campo das subjetividades ou no da produção de conhecimento, abrindo áreas de tensão com as tendências homogeneizantes.

Para Nicolescu (1999), a transdisciplinaridade pode ser entendida como uma forma de ser, saber e abordar, atravessando as fronteiras epistemológicas de cada ciência, praticando o diálogo dos saberes sem perder de vista a diversidade e a preservação da vida no planeta, construindo um texto contextualizado e personalizado de leitura dos fenômenos.

Em 1994, foi realizado o primeiro congresso mundial sobre a transdisciplinaridade, que presidido por Mário Soares reuniu, no Convento de Arrábida (Portugal), especialistas das áreas da ciência, letras, arte e religião, de diferentes localidades. Como memória do Congresso, ao final foi elaborado o projeto Carta da Transdisciplinaridade de autoria de Edgar Morin, Basarab Nicolescu e Lima de Freitas.

\footnotetext{
${ }^{6}$ Roque Theophilo, presidente da Academia Brasileira de Psicologia e Academia Internacional de Psicologia. Diretor Geral do Instituto Brasileiro de Estudos Sociais. Foi um dos fundadores do Conselho Federal de Psicologia, e um dos pioneiros da Psicologia no Brasil, conforme este site: <www.psicologia.org.br>.
} 
Conforme Mello (1999), a transdisciplinaridade tem sua origem no teorema de Gödel que em 1931 propôs distinguir os vários níveis de realidade. Com a comprovação na física, tal proposição demonstrou que o quanton é composto simultaneamente de ondas e corpúsculos (partícula), e que no seu nível a contradição entre onda e corpúsculo desaparece, constituindo uma unidade.

O teorema de Gödel, para Carniell e Rathjen (1990), é talvez o mais surpreendente e comentado resultado matemático do século, pois demonstrou que a inteligência humana será sempre superior às teorias formais e, portanto, sempre superior às máquinas. Os seus resultados dos teoremas da incompletude que revolucionaram a matemática, a lógica, a filosofia e a computação, foram publicados em 1930.

Nesse período, a partir da descoberta do teorema, a lógica clássica entra em crise, abalada em seu fundamento centrado na não contradição, e segundo Nicolescu (1999, p. 29), em termos matemáticos, a lógica clássica se expressa de acordo com os seguintes axiomas:

- O axioma da identidade: A é A;

- O axioma da não contradição: $A$ não é não $A$;

- O axioma do terceiro excluído: não há um termo $\mathrm{T}$, que é, ao mesmo tempo, $\mathrm{A}$ e não $\mathrm{A}$.

Como processo, para Mello (1999), "a lógica do terceiro termo incluído pressupõe o aparecimento de outros elementos contrapondo-se em qualquer nível de realidade transversal". De modo que é um processo sem fim e nesse sentido não há uma verdade absoluta, mas sempre verdades relativas e passíveis de mudanças no decorrer do tempo.

De certa forma, os temas transversais recuperam as relações existentes entre os conhecimentos e, consequentemente, mudam o conceito de conhecimento, passando da disciplinaridade à transdisciplinaridade (lógica do terceiro termo incluído).

Para Morin (2010), o desenvolvimento da ciência não se efetua por acumulação dos conhecimentos, mas por transformação dos princípios que organizam o conhecimento. Fundamentado nesse princípio, em 1960, ao lado Roland Barthes e Georges Friedmann, fundou o
Centro de Estudos de Comunicação em Massa (Cecmas), um laboratório dedicado ao estudo das mídias.

Existe algo entre e através de toda e qualquer disciplina? O espaço em questão é completamente vazio, como o vácuo para a física clássica?

Para Gleiser (1997), há vários níveis de realidade para as teorias da física, portanto, o espaço entre e além das disciplinas está cheio, como o vácuo quântico está cheio de todas as potencialidades: da partícula quântica às galáxias, do quark ${ }^{7}$ aos elementos pesados que condicionam o aparecimento da vida no Universo.

Consequentemente, parece que a estrutura descontínua dos níveis de realidade determina a estrutura descontínua do espaço transdisciplinar, que, por sua vez, pode explicar o motivo pelo qual a pesquisa transdisciplinar é distinta da pesquisa disciplinar, da qual é complementar.

Aquilo que se denomina de metodologia não é o mesmo e nem pode ser confundido com o conceito de método, para Morin (2010). De origem grega, a palavra "método" significa trajetória, e para esse autor foi o percurso no qual o caminho se fez ao andar e que naturalmente elaborou o próprio método.

As bases para o pensamento complexo se sustentam no constructo do que Morin (2010) chamou de operadores da complexidade, na ideia do que denominou tetralogia, e significa afirmar que qualquer ser vivo é gerado e influenciado pela natureza de quatro grandes potências, ou seja, a ordem, a desordem, interação e reorganização como processo constante e natural da vida.

O termo "operadores" é como uma indicação para as exigências que comportam os princípios que se confirmam durante o percurso, e que segundo Morin (2010) são significativamente representadas por três etapas da sua vida, denominadas princípio dialógico: princípio recursivo; princípio hologramático, e última etapa elaboração do método.

Para Morin (2010) o ser humano é de natureza unidual, ou seja, é $100 \%$ natureza e $100 \%$ cultura, porém possui obstáculos para reconhecimento dessa dualidade na unidade. Os

\footnotetext{
7 Segundo Gleiser (1997, p. 88), átomos são formados de elétrons, prótons e nêutrons. Prótons e nêutrons são formados de quarks. Portanto, a matéria é feita de quarks e elétrons.
} 
obstáculos geralmente são a razão, o racionalismo, a racionalidade e a racionalização como inibidores ou repressores do processo complexo.

Embora concebidas separadamente, a teoria da complexidade, também chamada de pensamento complexo, e a epistemologia da transdisciplinaridade articulam-se, e se vistas de maneira separada uma torna-se princípio da outra. O pensamento complexo foi sistematizado por Morin (1991), e a transdisciplinaridade por Nicolescu (1999).

\section{A teoria da complexidade}

Para justificar o seu posicionamento acerca do que chamou de natureza da natureza, Morin (2010) a princípio, pensou em tratar do problema da organização, nos limites das ideias sistêmicas e cibernéticas. Porém, na medida em que a pesquisa foi sendo realizada, descortinaram-se outras opções que incluíam as ideias iniciais num complexo de novas possibilidades.

A ideia de cibernética e de máquina, no percurso da construção teórica de Morin (2010) foi substituída pela expressão $p h y s i s^{8}$, significando que o universo físico deve ser concebido como o próprio lugar da criação e da organização, comum ao universo físico que compõe a vida.

Também é invocada a ideia de organização biológica e organização antropossocial ${ }^{9}$, mantendo o ponto de vista da ordem física. Para Morin (2010, p. 52) "a verdadeira realidade é ordem física, onde todas as coisas obedecem às leis da natureza; ordem biológica, onde todo indivíduo obedece à lei da espécie; ordem social, onde todo humano obedece à lei da cidade".

A organização é um conceito original e de natureza física, consequentemente nem a observação microfísica e nem a cosmofísica podem ser dissociadas de seu observador.

Ao observador, Morin (2010) reforça o princípio desse sujeito conhecedor, a priori, tal

\footnotetext{
${ }^{8} \mathrm{O}$ termo physis foi adotado por Morin para significar o universo físico.

${ }^{9} \mathrm{~A}$ expressão antropossocial é assim utilizada por Morin para significar que a verdadeira realidade é de ordem física, em que todas as coisas obedecem às leis da natureza; de ordem biológica, no qual todo indivíduo obedece à lei da espécie; e de ordem social, em que todo humano se submete à lei da cidade (MORIN, 2010, p. 52).
}

e qual aquele que pesquisa e se coloca como a categoria mais objetiva do saber, como o caráter circular da relação.

Na relação de cada dia que passa, a ciência se desdobra em micropossibilidades, pois por mais que uma unidade se comunique com a outra, o homem das ciências humanas é como um espectro suprafísico e suprabiológico.

A proposta de O Método para Morin (2010) é a pesquisa de um sistema capaz de articular o que está separado e reunir o que está disjunto, não somente no sentido linguístico, mas como expressão da realidade da dúvida que questiona a si mesma como símbolo anunciador da complexidade.

Nas pesquisas sobre as leis da natureza, observa-se que a ordem é soberana e imutável, e que a desordem não existe. Somente o determinismo e a parcialidade do olhar humano impedem de ver a plenitude universal.

Em termos de energia, "todo trabalho produz calor e isso contribui para a degradação". A essa diminuição irreversível da aptidão de se transformar e de efetuar um trabalho, própria do calor, foi denominado de entropia por Clausius (apud MORIN, 2010).

Em um sistema fechado, probabilisticamente, é maior a identificação de desordem e da desorganização, pois o universo é um megassistema fechado. Assim, para Morin (2010), o caminho é para a inelutável perspectiva rumo à desordem e à desorganização.

As partículas de um átomo aparentam ter a estética do sistema astral ou macrocósmica, e a realidade microfísica possui uma ordem que se diferencia em alguns aspectos do conceito mais comum ou tradicional de ordem e desordem. Segundo Morin (2010), uma desordem se constitui como parte de toda physis ou de todo ser físico, e mediante ela algo existe.

O que há no universo físico como as estrelas é "uma bomba de hidrogênio que arrebentará um dia", e nessa ideia o conceito de desordem substitui o lugar que ocupava a ideia de ordem, pois o universo desse ponto de vista de Morin (2010) é uma "diáspora explosiva", uma relação da desordem, a constituição da ordem e o desenvolvimento da organização.

No desenvolvimento da termodinâmica, segundo Prigogine (apud MORIN, 2010), não há necessariamente exclusão, mas eventualmente 
complementaridade entre fenômenos desordenados e organizadores, demonstrado no exemplo do Turbilhão de Bénard ${ }^{10}$.

Seguindo a ideia da termodinâmica, Morin (2010) acentua que quanto mais se volta no espaço-tempo, mais incertas ficam as observações e constatações, podendo gerar apenas uma aporia e crescendo a capacidade imaginativa humana, como ao analisar o Big Bang com o olhar sobre a catástrofe ou a desordem, que faz explodir algo que forma o que hoje se conhece como planeta Terra. Insinua que a ideia de catástrofe é inseparável de todo o universo, e afirma que não se trata de interrogar sobre os conhecimentos, mas que é preciso questionar sobre o entendimento do observador.

A potencialidade organizadora que envolve ordem e desordem, com as características antagônicas e complementares, é uma questão essencial para entender a gênese do método da teoria da complexidade proposta por Morin (2010).

O calor parece ser a força motriz e matriz da energia, dessa forma, o universo nasce no calor extremo que comporta as formas de desordem, agitação, turbulência, desigualdade de processos, caráter aleatório das interações e dispersão.

Para Morin (2010), a ordem nasce ao mesmo tempo que aparece a desordem da "catástrofe térmica que determina o processo constitutivo singular e factual do Universo".

Do ponto de vista arbitrário, os encontros podem ser considerados aleatórios, mas não é possível ignorar que alguma força de atração aproxima os elementos, e a partir desse encontro a ordem das leis é gerada.

As interações são inconcebíveis sem desordem, desigualdades, turbulências que provocam os encontros, sendo isso denomidano de circuito tetralógico por Morin (2010).

Nenhum elemento existe fora das interações que o constituíram e das quais esse mesmo elemento participa ativa e necessariamente. Por

\footnotetext{
${ }^{10}$ A experiência proposta por Bénard, citada por Prigogine (1972, p. 552-553) e por Morin (2010), se refere ao fenômeno da turbulência observada no líquido em ebulição, enquanto algumas moléculas sobem outras descem; de aparência caótica, mas extremamente organizado e coerente. Este fato aponta para uma característica do sistema complexo: a capacidade de auto-organização ou de comportamento emergente.
}

isso, pode-se entender que ordem e desordem existem apenas uma em função da outra.

A originalidade dessa teoria afirma que "não se pode dissociar o que está em harmonia do que não está", a não ser pelo exclusivo olhar do observador, somente no exato instante em que vê, pois depois poderá se modificar.

O caos para Morin (2010) está permanentemente subjacente como infraestrutura da physis, pois o "microuniverso representado pelo átomo que se consolida pelas moléculas tem a mesma edificação do Sol que representa o macrocosmo da galáxia".

[...] nenhuma dialética poderia esgotar, de uma só vez, o mistério do caos, o mistério da relação genésica/genérica do Caos a Logos (o desenvolvimento discursivo da ordem e da organização), de Urbis (a demência) a Dike (a medida), de Elohim (a gênese) a JHVH (a lei) (MORIN, 2010, p. 84).

O cosmos, como um duplo processo de organização e desintegração, para Morin (2010) não fornece garantia no caminho do pesquisador, apenas a insuperável incerteza de que deverá questionar os conceitos-mestres com os quais se aprisiona o mundo pelo pensamento.

O circuito irreversível resultante da catástrofe cósmica original que toma nova forma mediante a relação desordem/ordem/organização fica mais complexo quando enriquecido pela integração do segundo princípio da termodinâmica, pois segundo Morin (2010):

a) A desordem produz ordem e organização a partir das imposições iniciais e de interações;

b) A ordem e a organização produzem desordem, a partir de transformações;

c) Tudo que produz ordem e organização produz também irreversivelmente desordem.

O que ocorre primeiro é um "estado indizível, também chamado de acaso, acontecimento ou acidente, anterior à catástrofe e a seguir é que ordem e desordem nascem quase juntas e geram a dispersão, após a catástrofe".

Para Morin (2010), um fenômeno pode ser caracterizado como acaso quando o observador fica impotente para operar diante das formas singulares, o acidente se caracteriza por uma 
perturbação que provoca o reencontro entre um fenômeno organizado, e um acontecimento é o encontro eventual entre dois fenômenos.

Ao que Newton ${ }^{11}$ chamou de leis, a complexidade trata como condições, pois toda lei depende da eventualidade e as condições, sendo aleatórias, não obedecem às leis, apenas as condicionam.

O conceito condicionado de ordem se remodela diante das observações complexas, dado que a ordem passa a ser contextual e inseparável da matéria dos elementos que interagem como os átomos do corpo humano, dependendo da ordem gravitacional com o ambiente.

Neste sentido, Morin (2010) explica que a ordem também pode ser vista como "um grande mistério que paradoxalmente se evidencia e faz desaparecer a ideia de leis da natureza", para se afirmar com a questão da natureza das leis.

Nas relações entre ordem e desordem, parece importante caracterizar que tudo o que é organizado tende a acabar já que nasceu, enquanto ordem e organização são condenadas à morte, como um processo contínuo que se constrói e depois se modifica por circunstâncias naturais.

\section{A teoria da complexidade e a reforma do ensino}

Ao propor a reforma do ensino, no modelo da complexidade, Morin (2010) propõe ferramentas para pensar o cosmo, a natureza, o real e o humano de forma transdisciplinar e um verdadeiro renascimento cognitivo.

Como seria possível adotar e manter a atitude transdisciplinar na educação? Para Nicolescu (1999), o ideal talvez seja uma educação transdisciplinar, pois uma educação autêntica precisa privilegiar e ensinar a contextualizar, concretizar e globalizar. A educação transdisciplinar revaloriza o papel da intuição, do imaginário, da sensibilidade e do corpo na transmissão dos conhecimentos, seja para aquele que transmite como para o que recebe.

\footnotetext{
11 Isaac Newton foi um físico e matemático inglês, que viveu entre 1643 a 1727. Sua obra, Philosophiae Naturalis Principia Mathematica, descreve a lei da gravitação universal e as três leis de Newton, que fundamentaram a mecânica clássica, é considerada uma das leis mais influentes da história da ciência.
}

Desta forma, a questão da transdisciplinaridade pode interessar aos educadores como uma troca dinâmica entre as ciências exatas, as ciências humanas, a arte e a tradição, que pela procura de pontos de vista a partir dos quais seja possível tornar interativas a ciência e a religião propicia espaços de pensamento que as façam sair de sua unidade, como complementação à aproximação disciplinar, fazendo emergir da confrontação das disciplinas, dados novos que as articulem entre si.

Considerando que a transdisciplinaridade é o que está entre, através e além das disciplinas coloca-se em evidência uma visão emergente e uma nova atitude perante o saber e a natureza. Assim, desde criança se aprende que a natureza está ligada a tudo e para Morin (2010), a natureza não é dividida em disciplinas com fronteiras específicas como se faz na escola.

A disciplina é definida por Morin (2009) como uma categoria que organiza o conhecimento científico e nele institui conhecimento sobre a divisão e a especialização do trabalho. Assim, a ciência recobre e delimita fronteiras, pela linguagem que instaura, pelas técnicas que é levada a elaborar e utilizar, e por isso não basta conhecer apenas o interior de uma disciplina para saber dos problemas que lhe são afetos, mas também as suas interfaces dialógicas, ou seja, como a forma e conteúdo se relacionam.

Morin (2009, p. 52) afirma que "é necessário ir mais longe, pois a ciência nunca seria ciência se não tivesse sido transdisciplinar." A formalização e a matematização são os princípios fundamentais que permitiram desenvolver o enclausuramento disciplinar, pois não foi possível fazer a comunicação entre as diferentes dimensões do real senão abolindo estas dimensões, ou seja, unidimensionalizando o real.

A realidade do sistema de educação, de acordo com Morin (2010), necessita de revisão e constante vigilância por aqueles que se ocupam dos métodos educacionais nas escolas. Para esse autor existem basicamente sete pontos básicos para ser melhorados no sistema de ensino, denominados de "sete buracos negros".

Para tratar dos "sete buracos negros" no sistema educacional, ou sete problemas que não deve ter lugar nem nos programas de ensino, Morin (2009), propõe repensar e refletir sistemática e basicamente da seguinte forma: 
a) O conhecimento: mesmo que o sistema educacional se dedique a ensinar como obter o conhecimento, não apresenta os riscos de erros e ilusões que o conhecimento comporta, como fatos concretos já desvendados pela história universal em várias áreas do conhecimento.

b) O conhecimento pertinente: um conhecimento é pertinente se conseguir se situar em seu contexto e além dele, no conjunto ao qual está articulado, numa atitude que consiste em contextualizar o saber com outras possibilidades para ver o mesmo ponto a ser conhecido.

c) A condição humana: é o conhecimento da identidade humana e não é ensinado em nenhum lugar. Como afirmou Heidegger (apud MORIN, 2010, p. 292), jamais houve tanto conhecimento sobre o homem e jamais se soube menos o que é ser humano.

d) A compreensão humana: a compreensão é mais do que a explicação que trata da realidade humana como objeto. A compreensão visa entender o ser humano como sujeito e pode integrar a explicação, quando há esforço de empatia, identificação ou projeção.

e) A incerteza: o que se ensina é a certeza e não o enfrentamento das incertezas. $A$ ciência moderna precisa negociar com o incerto, como na termodinâmica, as relações de incerteza de Heinsenberg (apud MORIN, 2009, p. 95) ensinam que não se pode conhecer a posição de uma molécula ou de um gás, e assim em todos os aspectos da vida humana.

f) A era planetária: também conhecida como a "era moderna", seu maior objetivo seria fazer tomar consciência de que a Terra é apenas um planeta que não se situa no centro do mundo, mas integra o universo.

g) A antropoética: essa é uma referência à ética em escala humana, que leva em conta a inseparável trindade da condição humana indissociável: somos simultaneamente indivíduos, membros de uma sociedade e membros de uma espécie.

Além da proposta em repensar no sistema de ensino intitulado de "os sete saberes", Morin
(2010) também sugere a reforma na educação com acréscimo do ensino teórico sobre a civilização contemporânea nos seguintes temas:

a) O que é racionalidade?

b) O que é a ciência?

c) O que é a complexidade?

d) O que é o humanismo?

A partir da ideia de circulação reflexiva, Morin (2010) recomenda uma complexa reavaliação nas representações clássicas do sistema de ensino, mostrando os traços de vida e organização no mundo físico, na dependência de uma base química para o mundo do espírito humano e que, existe uma natural comunicabilidade entre a physis, biologia e antropossociologia.

Santos (2007) afirma que a "teoria da complexidade e a teoria da transdisciplinaridade sugerem a superação do modo de pensar dicotômico das dualidades (sujeito-objeto, parte-todo, razão-emoção etc.)". Na prática do magistério, esse novo referencial representa uma mudança epistemológica e indica novas coneitualizações de categorias analíticas.

A complexidade parece movimentar a condição humana na área da educação e, inclusive, sugere uma reflexão sobre a forma como são selecionados os professores para cada disciplina nas instituições de ensino. Será que o conhecimento específico em determinada área é o suficiente para a profissão de educador? Será possível manter a profissão de educador sem constante revisão de si mesmo no processo, especialmente os valores pessoais na relação com a Instituição em que formalmente ensina, com as salas de aula e tudo o que envolve a dinâmica de vida do educador? Será que o conhecimento técnico é o suficiente para o exercício do trabalho como educador? As bancas examinadoras de currículos, entrevistas e provas de conhecimento utilizam mecanismos adequados para a identificação de características pessoais para eleger um educador consistente e adequado à função?

De acordo com Morin (2010), o educador é aquele que mantém processos de educação de si mesmo como fundamento de tudo o que envolve sua vida, pois, sem essa condição, a escola está fadada ao fracasso do principal objetivo de formar cidadãos com princípios adequados.

A palavra antropoiética é utilizada por Morin (2005) para designar o fundamento 
da relação entre o indivíduo, a sociedade e respectiva espécie, num complexo contexto de vida que não se separa, mas que fica fundido e também dissociado.

A comunicação é a condição para que o ser humano se transforme essencialmente em sujeito que pertence a uma sociedade, segundo Freire (1997). Uma das suas proposições de maior fundamento para o autor é a de que a educação, como construção compartilhada de conhecimentos, constitui um processo de comunicação porque se gera mediante relações dialéticas. A construção do conhecimento não termina no objeto estudado, já que se comunica a outros sujeitos também abertos ao conhecimento sendo um processo interativo que, como processo significativo, constitui a essência e a estrutura fundamental no campo social da educação.

Sendo assim, como a educação pode estimular o estudante para uma prática de vida complexa se a metodologia e a didática tradicional não permitem essa reflexão?

Na educação tradicional que se estabeleceu no Brasil por volta de 1594, segundo Freire (1997), o professor devia colocar o conhecimento pronto dentro da cabeça do aluno que, por sua vez, devia reproduzir esse mesmo conhecimento da forma mais completa possível.

No pensamento complexo surgem paradigmas inovadores, em que ocorre o retorno da visão orgânica de mundo e agora ampliada pela ciência, seja na escola, como nas organizações que também se constituem como locais de contribuição para a educação do homem social.

De acordo com Freire (2001), o professor é também sujeito do processo e assim como o estudante é ativo, constrói sua história, é um ser dialógico capaz de gerar conhecimento levando em conta a natural transitoriedade e indeterminação das teorias.

A sala de aula é um local para absorver e estimular questionamentos, e por isso é necessário dialogar com o conteúdo das realidades sociais. Portanto, parece ser adequado o cuidado para proporcionar os meios adequados ao processo, como a ergonomia ${ }^{12}$ do ambiente da sala

\footnotetext{
12 Conforme a Associação Brasileira de Ergonomia (ABERGO) NR-17, ergonomia é o estudo científico de adaptação dos instrumentos, condições e ambiente de trabalho às capacidades psicofisiológicas, antropométricas e biomecânicas do homem. Portan-
}

de aula, a didática que possibilita o diálogo entre disciplinas, entre as culturas e necessariamente sobre identificação e gestão dos próprios talentos como estudante e educador.

As pessoas comprometidas com a educação e com a formação do ser humano, na opinião de De Aguiar (2005), podem considerar a universidade como um local apropriado para a formação de cidadãos e profissionais competentes. Contudo, tanto o pensamento complexo como a proposta de Freire (2001) parecem concordar que o ser humano precisa se educar permanentemente como uma experiência vital, pois onde há vida também existe inacabamento.

Portanto, a educação pode ser entendida como um processo constante e inconclusivo da vida humana, e o ensino transdisciplinar como uma metodologia muito apropriada na discussão epistemológica que caminha para estimular ações integradoras, que contemplam atitudes dialéticas complexas pertinentes.

\section{A teoria da complexidade no contexto da organização do trabalho}

Nas empresas, independente do produto gerado e do tamanho da estrutura, o princípio organizacional parece semelhante ao que a teoria da complexidade já enunciou como fenômeno que pode ser concebido e percebido, mas não pode ser explicado na totalidade por nenhuma lei simples.

A empresa está situada num determinado mercado e produz objetos ou serviços que entram no universo do consumo, portanto, se autoproduz e gera o que é necessário à sua sobrevivência e a de sua cultura.

A cultura de uma instituição é constituída pelas normas, valores e práticas que caracterizam uma empresa e a tornam única. Assim, trata-se do principal fator responsável pelo desenvolvimento de um sentido de unidade e participação coletiva, guardando diferença entre os membros de um grupo para outro, bem como as diferenças dentro do mesmo grupo entre um indivíduo e outro. Por isso que, para Schein (1987), a cultura organizacional é considerada como o "grande segredo, responsável pelo sucesso das

to, considera-se como uma ciência multidisciplinar 
empresas com melhor desempenho em longo prazo".

O conceito de cultura para Tamayo et al (2004) aglutinou em uma só palavra as possibilidades de realização do ser humano, além de evidenciar que a cultura é aprendida, ou seja, os hábitos e costumes de um grupamento social não representam aquisições inatas, meramente repassadas via mecanismo biológico. Pelo contrário, são produtos de um processo de construção sócio-histórica.

A complexidade da organização moderna, por mais volátil que seja em seu subsistema de capital, possui mecanismos e formas de controle parcial sobre o processo na organização do trabalho, envolvendo as teorias de gestão, a sociologia das organizações, a relação entre pessoas naquele ambiente, entre outras.

Segundo De Aguiar (2005), o ambiente da universidade, do ponto de vista do empresário, é um local onde são preparados profissionais capazes de exercer funções técnicas de forma competente em cada parte do sistema. A volatilidade desse sistema pode ser vista como um processo natural de relação sólida entre os sistemas que compõem o complexo organizacional.

De acordo com Bauman (2001, p. 14), "o que é sólido é moldado para sempre, mas manter os fluidos em uma forma requer muita atenção, vigilância constante e esforço perpétuo."

No esforço para manter a fluidez dos processos, mantendo no mínimo o mesmo nível de produção, diante das atuais e necessárias adequações organizacionais, podem também construir modelos consistentes para as organizações, pois a "teoria organizacional ainda busca num nível meta-teórico, definir melhor a relação entre epistemologia e organização." (CARON \& PONCHIROLLI, 2009).

A teoria da complexidade surge como no original enunciado de empresa ou organização, pois quem produz alguma coisa, produz a si próprio também em relação estreita com o processo complexo.

Para produzir a si próprio, para aprender sobre si e sobre a auto-observação também é necessário o exercício da lucidez conforme Morin (2008), como uma atitude reflexiva humana, que o torna capaz de considerar-se com relativas características cognitivas.
O cognitivismo se dedica ao estudo das possibilidades psicológicas humanas, inclusive do comportamento humano nas organizações ou no mundo do trabalho, segundo Freire (2010).

No ambiente do trabalho, a ciência da administração surge como uma área que se relaciona com várias outras ciências, no mesmo ambiente complexo e a partir de epistemologia específica.

Chevalier e Loschak (apud SERVA, 1992) fazem parte dos primeiros autores a empreender uma discussão essencialmente epistemológica na administração, ao indicar que a ciência da administração é uma ciência social ainda em gestação. De acordo com eles, o "objeto da administração necessita ser reconstruído à luz de uma problemática teórica específica" e para responder aos critérios de cientificidade deve superar certo número de obstáculos epistemológicos e desenvolver instrumentos de análise mais adequados.

Desta forma, a ciência da administração pode utilizar os conhecimentos de outras ciências a fim de apurar sua problemática, enriquecer os seus instrumentos conceituais e aperfeiçoar suas técnicas de investigação.

Partindo das teorias cientificistas de Taylor com as leis empíricas e de Fayol com os princípios lógicos, a formação epistemológica da teoria organizacional desabrocha fortemente durante a Segunda Revolução Industrial. (PONCHIROLLI, 2010).

A Segunda Guerra Mundial também proporcionou ambiente mais propício ao desenvolvimento de teorias organizacionais, considerando as regras para a administração gerencial de Estados-nação como uma grande empresa, e a aplicação de conceitos militares para confirmar na prática o que a teoria se propunha.

As pesquisas científicas em administração possuem limitações para o respectivo desenvolvimento, o que levou Campos (apud SERVA, 1992) a denominar de reducionismo a incompetência para lidar com contradições e a não apreciação da subjetividade nas teorias, e da capacidade essencial do ser humano de interpretar a realidade.

Guerreiro Ramos (1989) aborda que a epistemologia da administração não produziu mudanças significativas desde Taylor, que se limitou às questões técnicas, assim como Simon 
negligenciou os limites das regras de cognição inerentes às organizações. Dentre as limitações, destaca que o conceito de racionalidade predominante na teoria das organizações conduz ao entendimento de que o comportamento econômico constitui a totalidade da natureza humana. Também acentua que esta não distingue o significado substantivo do significado formal da organização, que não trabalha com a ideia clara do que compreende a interação simbólica no conjunto dos relacionamentos interpessoais e, ainda, que se apoia no pressuposto de que o homem é apenas um componente da força de trabalho, participando como item de custo.

Parece ser adequado também pensar que o campo da teoria da organização é um dos locais em que se concentram várias influências pela natureza do próprio espaço dialógico, porém, necessitando de uma avaliação criteriosa da condição desse campo para evitar que se transforme num local confuso, intolerante e sem direção assertiva ou inapropriada.

A criação tem como característica a elaboração de algo supostamente inusitado, diferente, descoberto casualmente e da colocação do conceito de forma mais adequada do que aquilo que até então foi admitido. Por isso, Kaplan (1964, p. 266) apud GUERREIRO RAMOS, 1989, p. 71) expõe sobre o esforço da formulação teórica da seguinte forma:

Não há duas coisas no mundo completamente iguais, de modo que toda analogia, por mais estreita que seja, pode ser levada a um extremo exagerado; por outro lado, não há duas coisas que sejam completamente dessemelhantes, de modo que sempre é possível estabelecer uma analogia, se nos decidirmos a fazer isso. A questão a ser considerada, em todos os casos, é se há ou não alguma coisa mais a aprender nessa analogia, se nos decidirmos a estabelecê-la.

Considerando os paradigmas vigentes nas teorias da administração, as dificuldades epistemológicas existentes podem receber grande contribuição da teoria da complexidade como sendo o paradigma emergente?

Para lidar com os paradigmas organizacionais, na visão de Guerreiro Ramos (1989), as teorias administrativas têm sido excessivamente simplificadas e demasiado globais, pois provavelmente partiu da ideia de que a organização era a mesma coisa que um indivíduo, isoladamente, ou que existia um único problema de motivação para toda a organização. Os processos organizacionais, consequentemente, teriam sempre a mesma resposta como uma psicologia individual.

A psicologia como ciência do comportamento humano tem sido muito útil para a compreensão do fenômeno organizacional, mas não pode ser vista na individualidade, dado que provavelmente esses indivíduos estão sob a influência das situações organizacionais, oferecendo, portanto, um ajustamento do fenômeno e do comportamento reciprocamente.

O que Guerreiro Ramos (1989) denomina de "ideologia integracionista" é uma tentativa de condução das ações organizacionais que podem perder de vista a necessária tensão entre as pessoas e os sistemas projetados. Contudo, essa tensão é o que retifica o mesmo sistema organizacional, relacionando as partes e o todo com precisão constituinte.

$\mathrm{Na}$ precisão das atividades cerebrais, a inteligência, a consciência e o pensamento são atividades com qualidades próprias e certa autonomia, que retroagem em círculos sobre as atividades originárias.

Morin (2008a) define a inteligência como arte estratégica, o pensamento como arte dialógica, e arte da percepção, a consciência como arte reflexiva, sabendo que constantemente interagem entre si.

$\mathrm{Na}$ inteligência estão os pressupostos pessoais para decidir, tomar decisões, resolver problemas e parece que na natureza também existe certo nível de inteligência, como uma planta que se enverga para buscar o sol, quando outras árvores à sua volta são maiores e ocupam mais espaço físico.

O reino animal também apresenta características aparentemente de uso da inteligência, como as estratégias ou astúcias peculiares ao caçador, tanto quanto da caça no processo de fuga. Por isso, a inteligência pode ter antecedido a própria espécie humana e considerando as várias espécies existentes, o desenvolvimento dos diversos tipos de inteligência também se deu em separado.

O problema da inteligência concerne diretamente ao problema do conhecimento, que depende da inteligência, dos conhecimentos de que dispõe (MORIN, 2008ª , p. 153). Por analogia, o 
conhecimento é um conhecimento do semelhante pelo semelhante que detecta, utiliza, produz similitudes de modo a identificar os objetos ou fenômenos que percebe ou concebe.

Tão vasto quanto o campo do conhecimento é a área da compreensão, pois esta é um modo fundamental de conhecimento antropossocial para Morin (2008a).

O processo da compreensão comporta limites para compreender a própria compreensão, com riscos de interpretação, especialmente quando se refere aos fenômenos humanos por mais perspicaz que seja, pois a explicação pode ser direcionada por mecanismos de defesa do ego psicológico como a projeção, identificação, sublimação e outros. Por isso, a compreensão deve ser fiscalizada, e sempre que possível verificada com procedimentos de explicação.

Parece não haver compreensão sem explicação, considerando que a explicação organiza a compreensão em virtude dos princípios ou regras que restabelecem a análise.

Nas civilizações de maneira geral são encontrados dois modos de conhecimento e de ação: um simbólico, mitológico ou mágico, e outro empírico, técnico ou racional, mas que em verdade são complementares entre si e estão em constante interação. (MORIN, 2008a).

O pensamento simbólico foi considerado por muito tempo pelo pensamento racional, como insuficiente para descrever a realidade, mas com a crise ou a insuficiência da racionalidade, a teoria do símbolo volta a ser reconhecida como potência da expressão da linguagem e, conforme Morin (2008a), "as noções de símbolo, mito e magia estão subentendidas umas nas outras", como se mostram na psicanálise que, explorando o inconsciente humano, descobriu essa esfera simbólica/mitológica/mágica no espírito humano.

Na prática organizacional, os símbolos de sucesso das carreiras, geralmente chamados de promoção para cargos de chefia e até contemplados pelos planos de carreira, de maneira geral privilegiam a boa execução de um trabalho, como forma de reconhecer um bom gestor. A falta de adequado plano de carreira bem como outros instrumentos de auxílio para gestão provavelmente impedem que o reconhecimento pertinente para promoção de determinado colaborador, seja primeiro na identificação de características diferentes entre as funções de gestão e as de execução.
A complexidade indica reflexões sobre a qualidade dos talentos de uma pessoa para o exercício das atividades profissionais, devendo, portanto, identificar essas características que de forma adequada podem ser utilizadas no campo do trabalho com assertividade ou pertinência.

Os símbolos sociais como status de certas funções, especialmente de gestão ou de suposto domínio do grupo de trabalho, são como símbolos de valor pertinentes àquele que exerce tal função, mas que nem sempre conseguem fluir com facilidade diante das condições que não combinam com sua cultura pessoal. Por isso, a complexidade também indica pensar sobre como são realizados os processos de seleção de pessoas para determinadas organizações? Como são realizadas as promoções dentro das organizações? Em que bases sistematizada ou consistente são realizadas as fases dos processos de qualificação? Com que argumentos são identificados os valores, as características necessárias para o exercício das funções, especialmente as de gestão nas organizações?

A noção de trabalho para Morin (2005) provém da experiência antropossocial e possui um sentido físico e também sociológico. O trabalho físico, por sua vez, é o produto ou o efeito de uma força por deslocamento do seu ponto de aplicação (p. 369). Do ponto de vista sociológico a organização do trabalho era rudimentar nas sociedades primatas, mas com o passar das épocas desenvolvem instrumentos para facilitar a caça, colheita e a defesa da comunidade, e se torna um problema organizacional central nas sociedades históricas.

A organização transforma, produz, religa, mantém, sendo o encadeamento de relações entre componentes que produz uma unidade complexa ou sistema, dotada de qualidades desconhecidas quanto aos componentes ou indivíduos. (MORIN, 2010).

Contudo, a inter-relação, organização e o sistema, apesar de inseparáveis, se diferenciam em algumas características.

A expressão unitas multiplex ${ }^{13}$ é utilizada por Morin (2010) para explicar que diferentes

\footnotetext{
${ }^{13}$ A expressão unitas multiplex é utilizada por Morin (2010, p. 135), citando Angyal (1941), para significar um paradoxo: considerado sob o ângulo do Todo, ele é homogêneo; considerado sob o ângulo dos constituintes, ele é diverso e heterogêneo. Desta forma, é a pluralidade do uno. A organização é a face interiorizada do sistema, e este se constitui como a face exteriorizada da organização.
} 
sistemas se apresentam como paradoxo, considerando sob o ângulo dos constituintes, diverso e heterogêneo. A complexidade de um sistema associa em si tanto a ideia de unidade quanto de diversidade.

Sendo assim como se constitui o conceito de sistema, é necessário o emprego das qualidades pessoais do sujeito que se comunica com o objeto; por isso, requer que a ciência física seja também entendida como ciência humana. Segundo esse autor, essa relação entre objeto e observador exige que este último observe a si mesmo investigando o sistema, e se esforce para entender o seu conhecimento.

A concepção de máquina segundo tal autor envolve todo elemento (ser) físico cuja atividade comporta trabalho, transformação e produção, e toda organização ativa pode ser concebida como máquina. A máquina é considerada um ser físico organizador, logicamente com o caráter sociológico humano, mas que torna a sociedade dependente da máquina que ela mesma criou.

As ações da máquina são produzidas em função de propriedades organizacionais, e Morin (2010) denomia competência a aptidão organizacional para condicionar ou determinar certa diversidade de ações, como também intituta práxis o conjunto de atividades que efetuam transformações a partir de uma competência. As práxis são ações com caráter organizacional, e por isso que são qualificadas de sistemas práxicos aqueles que possuem organização ativa.

Consequentemente, a ideia de produzir significa conduzir ao ser ou à existência de algo, como resultado das interações criadoras.

As interações ocorrem por meio biológico, humano, social como matéria física, ou seja, é o mesmo conceito de máquina, um dos mais físicos que se pode conceber sendo ao mesmo tempo uma construção intelectual complexa.

Portanto, para Morin (2010) o observador deve necessariamente interrogar a sua concepção de sociedade e a de ciência. Sobretudo, deve suspeitar e questionar a si mesmo se deseja produzir um conceito complexo, que possa se aplicar a seres existentes desiguais sem anular suas diferenças, que mantenha respeito pela extraordinária diversidade do universo das máquinas, ou se ele não deseja intelectualmente produzir o reducionismo físico e a mutilação da verdade.
O foco ideal da proposta apresentada pelo método de Morin (2010) é o circuito, o encaminhamento organizador do método que leva a fisicalizar as noções, em seguida socializá-las, depois fisicalizá-las outra vez e novamente socializá-las ao infinito. Esse não é um círculo vicioso, mas uma práxis produtiva, pois se dá numa condição aberta e alimentada constantemente para gerar o que Marx (apud MORIN, 2010, p. 346) intitulou produção.

Para construir a ideia de organização proposta por Morin (2010), também foram utilizados os conceitos de entropia e neguentropia, pois a organização é o que envolve e liga neguentropia e informação.

O conceito de entropia apresentado por Schrodinger em 1945 (apud MORIN, 2010) reforça a ideia de que tudo no universo está em constante movimento, como o suco de uma fruta que não pode mais voltar à antiga forma. Esse fenômeno é apresentado pelo conceito de irreversibilidade do tempo, considerando que as combinações ocorrem nas relações entre as coisas e não se repetem. Por isso, a segunda lei da termodinâmica afirma que a irreversibilidade de um sistema está relacionada com sua entropia, uma medida de sua complexidade.

O conceito de neguentropia apresentado por Morin (2010) é o aspecto termodinâmico de toda regeneração, reorganização, produção, reprodução de organização, numa relação indissolúvel e que promove o crescimento da entropia.

A entropia e neguentropia constituem a mesma grandeza e, portanto, os processos antagônicos da mesma organização: desorganização e degenerescência de uma parte, reorganização e regeneração ou desenvolvimento e complexificação de outra.

Resumidamente, a neguentropia reina no interior do sistema, segundo Morin (2010), e despeja a entropia para o exterior, como um subproduto da sua atividade, semelhante ao conceito de desorganização/reorganização permanente. O mesmo fenômeno que combate a desorganização é o mesmo que renova as mesmas causas.

O conceito ou as ideias da neguentropia introduzem a ideia da informação, pois os seres vivos assim como as máquinas são constituídos por relações organizacionais comunicacionais, 
seja por reações químicas ou por comportamento dos circuitos tecnológicos.

A cultura, segundo Morin (2010), constitui um complexo regenerativo informacional matricial, que perpetua a complexidade, originalidade, identidade de cada sociedade e se reproduz através dos cérebros. Assim também pode ser visto o surgimento do aparelho de Estado, semelhante à passagem do unicelular para o organismo pluricelular.

O aparelho Estado possui dependências que se perturbam, como os bancos e empresas na vida econômica; e os partidos na vida política, que concentram em si a potência generativa de regras sociais.

Na ideia do tetragrama ou tetrálogo apresentado por Morin (2010), a desordem, as interações, a ordem e organização constituem ligações que indicam que tudo o que é gerado também se gasta e precisa ser regenerado, portanto, o que é genésico, gerador e criador não se priva da desordem.

A complexidade aqui proposta por Morin (2010) corresponde à irrupção dos antagonismos dos fenômenos ou das contradições da essência das teorias, como pensar junto e de forma coerente com ideias contrárias. Para tanto, é necessário localizar o meta ponto de vista que relativiza a contradição, e a inscrição em um circuito que torna produtiva e complementar a associação.

No pensamento complexo é necessário aproximar o que Morin (2010) denomia "objeto conhecente", ou seja, o saber transforma o observador. Se o objeto é aproximado do saber que transforma o observador, então provavelmente ocorre a produção do autoconhecimento na e da vida.

A partir do prefixo "auto", Morin (2005, p. 129) questiona: qual é a autonomia da organização e da ação que produz e é produzida pela autonomia de um ser individual e de uma existência viva, constituindo um processo transindividual de autorreprodução? Ao prefixo auto, falta um conceito consistente, evidente, pois gera uma incógnita ou enigma da vida.

A noção do prefixo "auto" restitui os sentidos inseparáveis de uma forma direta, que tem o mesmo significado; e o reflexivo, que supõe a si mesmo. Morin (2005) constantemente designa o retorno do mesmo através dos ciclos de repro- dução, e o idêntico, que define uma espécie, a identidade e um indivíduo, concedendo sentido vivo ao termo organização, como também aos termos reprodução e produção.

Assim como ocorre a autorreprodução, os sistemas vivos possuem a capacidade de autoproduzir-se de modo permanente, e isso constitui a principal característica desse sistema denominado de autopoiesis ${ }^{14}$ por Maturana, Varela e Uribe (apud MORIN, 2005, p. 130) em 1972.

A sociedade humana, no desenvolvimento da organização do trabalho se depara com o problema fundamental da auto-organização e, segundo Morin (2005), a complexidade pode esclarecer sobre as simplificações e falsas evidências que são utilizadas sobre a especialização, a hierarquia e a centralização antropossocial, que adquirem sentido unidimensional técnico ou econômico.

De acordo com esse autor, no segmento social do trabalho, o desenvolvimento da racionalidade e da eficácia são impostos e exigidos pelo centro de comando e controle, a começar pela hierarquia entre os que decidem e executam uma divisão do trabalho com as inúmeras especializações, e conforme o progresso tecnológico.

A organização do trabalho é semelhante a um organismo biológico que possui a sede central de comando no cérebro e os órgãos e células seguem uma hierarquia, enquanto uma prodigiosa especialização ocorre na constituição somática nas atividades das células e moléculas.

A especialização possui vantagens no aumento das qualidades organizacionais como a precisão e eficácia, mas pode determinar a diminuição de autonomia e consequentemente inibição de outras potencialidades.

Assim também a complexidade pode observar a especialização no segmento da vida humana em organizações, em que o ser humano possui especialidades que não são separadas das não especialidades.

O desenvolvimento das bases da complexidade na organização do trabalho pode gerar o desenvolvimento de polivalências, que Morin

\footnotetext{
${ }^{14}$ Autopoiesis pode ser entendida como a criação de novos sentidos que ocorre porque o domínio da linguagem se autorreproduz de forma não rígida e evolui em seu próprio grau independente de complexificação e criação de novas formas. (MORIN, 2005, p. 130).
} 
(2005) denominou de organização viva. Assim como o aparelho neurocerebral, a organização viva associa, combina e opõe especialização, não especialização, poliespecialização, antiespecialização.

Morin (2005) acentua que no universo antropossocial, o indivíduo vive simultaneamente para ele e para a sociedade, pois constituem (indivíduo com seu Estado) a mesma organização, e se combinam e complementam como também são antagônicos e por isso mesmo, precisam de estratégias como num jogo da vida.

O homem do futuro já está presente na interação social, pois é isso que o constitui. Porém, o sistema social é um todo organizador que retroage sobre seus componentes e assegura sua natureza original e equilibrada.

\section{Considerações finais}

O conhecimento total de todo o universo jamais será atingido, segundo Morin (2010), mas se deve aspirar a um conhecimento multidimensional.

O método desenvolvido por esse autor é uma tentativa abrangente de articular os vários tipos e níveis de conhecimento das ciências, especialmente as ciências físicas, biológicas e dos saberes antropossociológicos, o que é visto por Vasconcelos (2009) como um "antimétodo, dado que toma como ponto de partida a negação das falsas clarezas, do claro e distinto, e do conhecimento supostamente seguro".

A escola pode incentivar a comunicação entre as diversas áreas do saber e a busca das relações entre os campos do conhecimento, "desmoronando as fronteiras que inibem e reprimem a aprendizagem". (PETRÁGLIA, 1995). Trata-se da transcendência do pensamento linear que sozinho é reducionista, pois "a transdisciplinaridade é a prática do que une o múltiplo e o diverso no processo de construção do conhecimento".

Conforme Lorieri (2010) é necessário aprender a construir passarelas relacionais sem perder de vista as localidades. Há necessidade de desenvolver um pensamento apto a perceber as ligações, interações, implicações mútuas e ao mesmo tempo, a diferenciação, oposição, seleção e a exclusão. Ambas as percepções são necessárias.
A tetralogia pode ser compreendida como uma dimensão mística, humana e pessoal, mas é uma experiência de não separação e, de qualquer modo, Morin (2010, p. 345) "sente-se convencido de que é necessário estudar o xamanismo não somente como curiosidade etnográfica e não somente pelos poderes curativos, mas principalmente por ser a fonte mais arcaica, mais profunda e misteriosa dos conhecimentos humanos".

O xamanismo, conforme Gurdjieff (2010), é uma tradição ou uma forma de viver, em que as pessoas se dedicam aos relacionamentos com todas as coisas, e com todos os fatos e fenômenos, como se fossem organismos vivos e com inteligência múltipla desde sua origem. A palavra xamanismo significa aproximadamente "aquele que sabe", num sentido em que cada ser pode saber de si mesmo, como única forma de aprender como se relacionar com o outro com quem convive.

A comunhão psicológica sugere ser o caminho necessário para cada indivíduo ter, para si mesmo, a condição de direcionar esforços na vida a fim de lograr êxito nas suas atividades profissionais. A complexidade pode ser um meio para que o ser psíquico destrone ilusões que são assimiladas apenas pela espécie, mas não para a individualidade integrada num sistema cultural.

Nessa concepção de mundo transdisciplinar, o desafio parece ser grande, mas necessário, para poder transitar pela diversidade dos conhecimentos com espírito livre e sem fronteiras epistemológicas rígidas. Isso requer postura adequada ao conceito, mesmo que necessite mudar a forma de fazer as coisas e fazê-las de um jeito diferente em tempos modernos.

As teorias administrativas, transversalmente, podem ganhar apoio ao debate pela complexidade, e finalmente produzir pesquisas mais profundas sobre o fenômeno organizacional. Conforme Vergara e Peci (2003), grande parte das pesquisas desenvolvidas na área conclui que ainda se apresentam métodos tradicionais de orientação positivista e funcionalista. Fato que também não pode ser desconsiderado é que a política institucional na construção de conhecimento muitas vezes coloca os pesquisadores numa condição de reféns da própria linguagem, em consequência do que está institucionalizado há vários anos. 
Guerreiro Ramos (1989) ressalta que é o momento de revisar o ponto cego das teorias organizacionais atualmente utilizadas, para um avanço epistemológico substantivo. A colocação inapropriada de conceitos impregna a literatura contemporânea sobre tópicos e problemas organizacionais, semelhante à confusão ensurdecedora de línguas que causam deformações.

A teoria da complexidade poderia contribuir com o debate educativo, ou se constituir numa forma epistemológica para as teorias organizacionais e do trabalho?

A transdisciplinaridade apresentada por Morin, como a epistemologia da teoria da complexidade nesse estudo, é apresentada como capaz de interligar conhecimentos que jamais se concluem. Neste sentido, o que aqui se observa e é objeto de uma das perguntas norteadoras desta pesquisa, é que a teoria da complexidade se institui como uma epistemologia adequada a contribuir com a dialógica nas teorias educacionais e nas organizações do trabalho, sempre que se desejar constituir instrumentos reflexivos de continuidade para a dinâmica natural do comportamento humano e organizacional.

E é mediante a ciência do comportamento humano que nesta pesquisa buscou-se verificar também as características da teoria da complexidade relacionando-as com a forma de vida do autor. Visto que o cientista é também objeto de sua própria observação, a vida de Morin se constitui como referência para o enunciado teórico e isso reforça o que se observa como conclusivo até o momento.

A escola é reconhecidamente o local do desenvolvimento humano complexo, antes das demais empresas e depois das culturas familiares. Por isso, a área da educação que também é considerada uma empresa ou uma organização do trabalho, somente pode receber como educador aquele que já possui o consistente processo de educação. A história social convencionou que a escola é o local do desenvolvimento profissional, em que profissões são ensinadas com comportamentos pertinentes ao exercício de cada profissão.

As características da epistemologia da transdisciplinaridade, apresentadas por Morin, também aparecem na sua história de vida, o que sugere que essa é a epistemologia adequada para ele, sendo que isso também o constitui como sujeito psicológico da própria pesquisa.

Assim como na teoria da complexidade proposta por Morin, as teorias psicológicas justificam que as consequências da vida humana estão em estreita relação com aquilo que cada indivíduo produz, seja no espaço ínfimo da consciência como no amplo segmento da inconsciência.

Segundo a pesquisa, é necessário que cada indivíduo saiba basicamente se locomover diante das circunstâncias da vida, especialmente relatando para si as experiências cotidianas e naturais das relações de conflito ou diferenças, mas que não necessariamente são desfavoráveis a importantes aprendizados, como observado na própria vida de Morin.

Para que o indivíduo saiba reconhecer em si mesmo as principais características que o qualificam para relações específicas, as teorias psicológicas afirmam que é necessário ter condições que coloquem o indivíduo em contato consigo mesmo, sendo, portanto, uma espécie de treinamento para o autoconhecimento.

O que se propõe também nessa pesquisa é a estimulação de canais identificados como na área da educação e nas organizações do trabalho, como fatores estimulantes do reconhecimento psicológico e humano. São esses lugares sociais que funcionam como condutores da dimensão dos valores humanos, que mediante pesquisas consistentes de linguagem adequada possam contribuir socialmente com o reconhecimento ou autoconhecimento pertinente.

Segundo a teoria da complexidade, a escola e a empresa não podem perder a oportunidade de humanizar ainda mais o ser humano que ali se constitui, e que cada profissão seja definida com caráter da verdade dos talentos pessoais a serviço da produção de benefícios gerais, como a satisfação pessoal e social.

Desta forma, para Morin (2010) o educador deve educar a si mesmo, para somente assim exercer seu verdadeiro papel de educador, se for esse o local de sua afinidade e se for para estar em paz, no fim.

Como processo dinâmico, com o tempo a ciência evidencia as próprias limitações e pode nem se dar conta disso, mas pode-se pensar em permitir que a transversalidade da complexidade se apresente numa perspectiva 
crítica ao fenômeno organizacional, educacional e cognitivo.

Tendo em vista o que aqui se observa, a epistemologia transdisciplinar fica caracterizada e justificada na obra de Morin, como também argumenta utilizar o método complexo para manter e ampliar debates na educação e nas organizações, considerando que a educação também pode ser observada como organização do trabalho educacional, e assim se configura como objeto de investigações futuras e emergentes.

\section{Referências}

AXELROD, R.; COHEN, M. Harnessing complexity: organizational implications of a scientific frontier. Nova York: The Free Press, 1999.

BAUMAN, Z. Modernidade líquida. Rio de Janeiro: Zahar, 2001.

BERMAN, M. Tudo o que é sólido desmancha no ar. São Paulo: Companhia das Letras, 2007.

BOHM, D. Wholeness and the implicate order. Londres: Routledge \& KeganPaul, 1980.

BOHR, N. Atomic physics and human knowledge. Nova York: Science Editions Inc., 1961.

CARNIELLI, W. A.; RATHJEN, M. Combinatória e indemonstrabilidade, ou o $13^{\circ}$ trabalho de Hércules. Mathemática Universitária, n.12, 1990.

CARON, A.; PONCHIROLLI, O. (Orgs.). Globalização, organizações e estratégias empresariais. São Paulo: Atlas, 2009.

CARTA de Transdisciplinaridade. Adotada no Primeiro Congresso Mundial da Transdisciplinaridade, Convento de Arrábida, Portugal, 2 a 6 nov. 1994. Disponível em: <www.perso.club-internet.fr/nicol/ ciret/>. Acesso em: 21 fev. 2013.

CARVALHO, E. A. Prefácio. In: GALENO, A; CASTRO, G. de; COSTA DA SILVA, J. (Orgs.). Complexidade à flor da pele. São Paulo: Cortez, 2003. p. 11-15.

CARVALHO, J. C. de P. Antropologia das organizações e educação: um ensaio holonômico. Rio de Janeiro: Imago, 1990.

CENTRE INTERNATIONAL DE RECHERCHES ET ÉTUDES TRANSDISCIPLINAIRES. Disponível em: $<$ www.psicologia.org.br/internacional/universidades. htm>. Acesso em: 12 ago. 2012.
CETRANS. Comunicado final. Ciência e Tradição: perspectivas Transdisciplinares para o século XXI. In: CONGRESSO UITF. Paris, Unesco, 2 a 6 de dezembro de 1991. Disponível em: <www.cetrans.futuro.usp.br/ cartadatransport.html>. Acesso em: 21 fev. 2013.

CHEVALLIER, J.; LOSCHAK, D. A ciência administrativa. Mem Martins: Europa-America, 1980.

DE AGUIAR, M. A. F. Psicologia aplicada è administração: uma abordagem interdisciplinar. São Paulo: Saraiva, 2005.

DELEUZE, G.; GUATTARI, F. Capitalisme et schizophrénie: mille plateaux. Paris: Minuit, 1980.

EDINGER, E. F. Ego e arquétipo. São Paulo: Cultrix, 1972.

FADIMAN, J.; FRAGER, R. Teorias da personalidade. São Paulo: Harbra, 1986.

FREIRE, I. R. Raízes da psicologia. Petrópolis: Vozes, 2010.

FREIRE, P. A educação do futuro. O Globo, Rio de janeiro, 24 maio 1997, Caderno Prosa \& Verso.

Educação como prática de liberdade. Rio de Janeiro: Paz e Terra, 2001.

GARCIA, F. C.; BRONZO, M. As bases epistemológicas do pensamento administrativo convencional e a crítica à teoria das organizações. In: ENCONTRO DE ESTUDOS ORGANIZACIONAIS DA ASSOCIAÇÃO NACIONAL DE PÓS-GRADUAÇÃO E PESQUISA EM ADMINISTRAÇÃO, 1, 2000, Curitiba. Anais... Curitiba: ANPAD, 2000.

GIDDENS, A. A constituição da sociedade. São Paulo: Martins Fontes, 1989.

GLEISER, M. A dança do universo. São Paulo: Companhia das Letras, 1997.

Caos e complexidade: a evolução do pensamento econômico. Rio de Janeiro: Editora Campus, 2002.

GUATTARI, F. Caosmose. Rio de Janeiro: Editora 34, 1992.

GUERREIRO RAMOS A. Administração e estratégia do desenvolvimento : elementos de uma sociologia especial da administração. Rio de Janeiro: FGV, 1966.

A nova ciência das organizações: uma reconceituação da riqueza das nações, São Paulo: FGV, 1989. 
. Uma introdução ao histórico da organização racional do trabalho. Brasília: Conselho Federal de Administração, 2009.

GURDJIEFF, J. E o lobo uivou para a águia: espiritualidade como prática de vida. Nova Petrópolis: Luz da Serra, 2010.

HEISENBERG, W. Physics and philosophy: the revolution in modern science. Nova York: Harper Torcbooks, 1962.

A parte e o todo: encontro e conversas sobre física, filosofia, religião e política. Rio de Janeiro: Contraponto, 1996.

HOUAISS, A.; VILLAR, M. de S. Dicionário Houaiss da língua portuguesa. Rio de Janeiro: Objetiva, 2001.

JAPIASSU, H. O sonho transdisciplinar e as razões da Filosofia. Rio de Janeiro: Imago, 2006.

JUNG, C. G. O eu e o inconsciente. Petrópolis: Vozes, 1987.

AION-Estudos sobre o simbilismo do simesmo. Petrópolis: Vozes, 1990. 1994.

Psicologia e alquimia. Petrópolis: Vozes,

. O homem e seus símbolos. Rio de Janeiro: Nova Fronteira, 1998.

JUNG. E. Animus e Anima. São Paulo: Cultrix, 2006.

KUHN, T. A estrutura das revoluções científicas. São Paulo: Perspectiva, 1987.

LAPLANCHE, J. Vocabulário da psicanálise. São Paulo; Martins Fontes, 1992.

LÉVY, P. Cibercultura. Rio de Janeiro: Editora 34, 2000.

LIBÂNEO, J. C. As teorias pedagógicas modernas revisitadas pelo debate contemporâneo na educação. In: LIBÂNEO, J. C.; SANTOS, A. (Orgs.). Educação na era do conhecimento em rede e transdisciplinaridade. Campinas: Alínea, 2005. p. 19-63.

LORIERI, M. A. Complexidade, interdisciplinaridade, transdisciplinaridade e formação de professores. São Paulo: PPGE Uninove, 2010. Disponível em: <www.scielo.org>. Acesso em: 15 out. 2012.

MATURANA, H.; VARELA, F. A árvore do conhecimento. Campinas: Ed. Psy II, 1995.
MELLO, M. F. de. Transdisciplinaridade, uma visão emergente: um projeto transdisciplinar. 1999. Disponível em: <www.cetrans.futuro.usp.br/ gödelianos.htm>. Acesso em: 11 jun. 2012.

MORIN, E. Meu caminho. Rio de Janeiro: Bertrand Brasil, 2010. (Entrevistas com Djénane Kareh Tager).

. Educação e complexidade: os sete saberes e outros ensaios. São Paulo: Cortez, 2009.

0 método I: a natureza da natureza. Porto Alegre: Sulina, 2008a. Sulina, 2005

O método II: a vida da vida. Porto Alegre:

O método III: o conhecimento do conhecimento. Porto Alegre: Sulina, 2008b.

2008c.

O método IV: as ideias. Porto Alegre: Sulina,

O método V: a humanidade da humanidade. Porto Alegre: Sulina, 2007.

A cabeça bem feita: repensar a reforma, reformar o pensamento. Rio de Janeiro: Bertrand Brasil, 2003.

1997

O homem e a morte. Rio de Janeiro: Imago,

Introdução ao pensamento complexo. Lisboa: Instituto Piaget, 1991.

Problema epistemológico da complexidade. Lisboa: Europa-América, 1983.

NICOLESCU, B. O manifesto da transdisciplinaridade. São Paulo: Trion, 1999.

A visão do que há entre e além. Caderno Cultura, Lisboa, 3 de fevereiro de 1994, p. 2-3. (Entrevista para Antónia de Sousa).

Definition of transdisciplinarity. 2003. Disponível em: <www.interdisciplines.org/ interdisciplinarity/papers/5/24>. Acesso em: 15 ago. 2012.

NICOLIS, G.; PRIGOGINE, I. Exploring complexity. Nova York: W. H. Freeman and Company, 1989.

ORTI, P. S.; ALBINO, J. P.; MANFRINATO, J. W. S. Diagnóstico de modelos de maturidade em educação corporativa: proposta de instrumento avaliado em pesquisa piloto em instituições financeiras. Revista do CCEI, Bagé, Universidade da Região da Campanha, v. 1, n. 1, out. 1997. 
PAUL, P. Formation du sujet et transdisciplinarité.

Paris/Montreal: L'Harmattan, 2003.

PETRAGLIA, I. C. Edgar Morin: a educação e a complexidade do ser e do saber. Petrópolis: Vozes, 1995.

PONCHIROLLI, O. Capital Humano: sua importância na gestão estratégica do conhecimento, Curitiba: JURUÁ, 2010.

PRIGOGINE, I. O fim das certezas: tempo, caos e as leis da natureza. São Paulo: UNESP, 1996.

REDE BRASILEIRADE TRANSDISCIPLINARIDADE. Que universidade para o amanhã? Em busca de uma evolução transdisciplinar da universidade. In: CONGRESSO DE LACARNO. Anais... Locarno, Suiça, 2010. Disponível em: <www. redebrasileiradetransdisciplinaridade.org>. Acesso em: 21 jul. 2012.

SANTOS, A. Complexidade e transdisciplinaridade em educação: cinco princípios para resgatar o elo perdido. Curitiba: EBEC, 2007. Disponível em: <www. ufrrj.br/leptrans>. Acesso em: 01 out. 2012.

SCHEIN, E. Psicologia organizacional. Rio de Janeiro: Prentice-Hall do Brasil, 1982.

SERVA, M. O paradigma da complexidade e a análise organizacional. Revista de Administração de Empresas, São Paulo, v. 32, n. 2, p. 26-35, 1992.

SCIELO. Disponível em: <www.scielo.br>. Acesso em: 19 set. 2012.

TALBOT, M. O universo holográfico. São Paulo: Best Seller, 1991.

TAMAYO, A. et al. Cultura e saúde nas organizações. Porto Alegre: Artmed, 2004.

THIOLLENT, M. Metodologia de pesquisa-ação. 4. ed. São Paulo: Cortez, 1988.

VASCONCELOS. E. M. Complexidade e pesquisa interdisciplinar: epistemologia e metodologia operativa. Petrópolis: Vozes, 2009.

VERGARA, S.C.; PECI, A. Escolhas metodológicas em estudos organizacionais. Revista Organizações \& Sociedade, v. 10, n. 27, 2003.

WEIL, P.; D'AMBRosio, U.; CREMA, R. Rumo à nava transdisciplinaridade. São Paulo: Summus, 1993. 